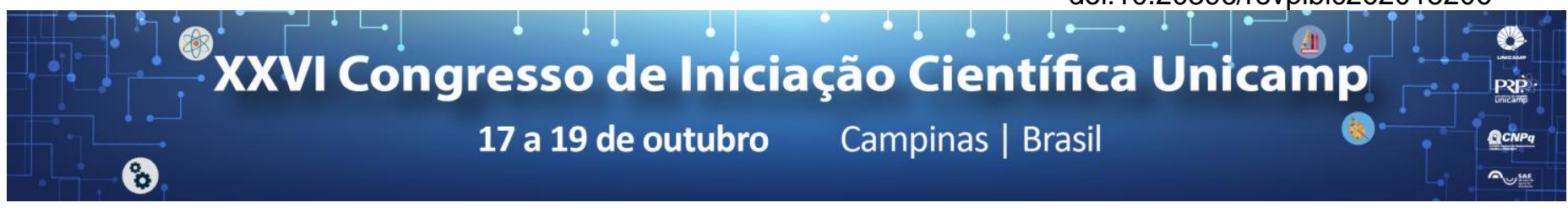

\title{
A Vila Andrade em São Paulo e a nova fronteira de expansão da produção imobiliária
}

\section{Beatriz T.L.Soares*, Sidney P. Bernardini.}

\section{Resumo}

A criação, ainda na década de 1980 , de um novo centro comercial na cidade de São Paulo, no chamado "vetor sudoeste", acarretou diversas mudanças no contexto urbano da cidade. A construção da Avenida Eng. Luiz Carlos Berrini e do Centro Empresarial São Paulo, atraiu diversas multinacionais a instalarem suas sedes nessa região. Com o grande contingente de pessoas atraídas por empregos, abriu-se um grande potencial para o desenvolvimento de um parque imobiliário residencial nas vizinhanças próximas, como na Vila Andrade. Loteado sobre a chácara Tangará, o bairro era pouco ocupado até aproximadamente a década de 1980. A partir de 1986, entretanto, sua ocupação por edifícios residenciais passou a se intensificar e a criação do parque Burle Marx, na década de 1990, trouxe mais atrativos para a região, que passou a despertar ainda mais o interesse de incorporadoras e construtoras.

\section{Palavras-chave: \\ Urbanização, Produção imobiliária, Planejamento municipal, São Paulo}

\section{Introdução}

Por apresentar grandes áreas livres, boa localização e boa infraestrutura, além de preços mais baixos que seus vizinhos, Morumbi e Brooklin, sem as restrições de zoneamento presentes nestes dois bairros, o distrito passou a apresentar a maior taxa geométrica de crescimento populacional do município de São Paulo entre 2000 e 2010, pari passu ao maior número de lançamento de empreendimentos imobiliários da capital entre os anos de 1992 e 2016, que segundo dados da EMBRAESP teve 641 lançamentos no período, o que sugere tratar-se da mais nova frente de desenvolvimento imobiliário no vetor sudoeste, historicamente ocupado, conforme aponta a literatura, pelas camadas populacionais de alta renda.

\section{Resultados e Discussão}

Com o objetivo de compreender e analisar os aspectos intrínsecos a esta alteração na fisionomia do bairro e compará-los com os instrumentos de planejamento instituídos, a pesquisa apresentou como resultados que o zoneamento do distrito contribui enormemente para a forma de ocupação encontrada nele, distritos exclusivamente residenciais de baixa densidade e zonas mistas de média e alta densidade, que compõem grande parte do distrito e possuem coeficiente de aproveitamento igual a 4, possibilitando a construção de empreendimentos residenciais que caracterizam a região. A partir dos dados da Embraesp, foi possível constatar que $96,39 \%$ dos empreendimentos lançados no distrito, entre 1985 e 2013, são verticais, 73,68\% possuem três ou mais dormitórios, 75,04\% possuem duas ou mais vagas de garagem e $60 \%$ das unidades produzidas são maiores que $193 \mathrm{~m}^{2}$.

\section{Conclusões}

A partir dos dados coletados, da análise dos planos e dos estudos de campo foi possível perceber que a fisionomia urbanística e paisagística desta nova frente imobiliária é caracterizada pela formação de enclaves, condomínios verticais murados e cercados e os espaços públicos decorrentes são, em geral, pouco adequados à caminhabilidade, sem qualidade urbanística. A ausência de uso do solo mais diversificado também acentua a falta de apropriação do espaço público no bairro, demonstrando ser esta a principal característica urbanística de alguns novos assentamentos urbanos contemporâneos das camadas de média e alta renda no Brasil.

\footnotetext{
1 BARROSO, Daniella Almeida. Projeto Urbanístico Panamby: uma 'nova cidade' dentro de São Paulo?: Análise do parcelamento e loteamento da Chácara Tangará. 99 f. Dissertação (Mestrado) - Faculdade de Filosofia, Letras e Ciências Humanas, Universidade de São Paulo, São Paulo, 2006.

2 VOLOCHKO, Danilo. A produção do espaço e as estratégias reprodutivas do capital: negócios imobiliários e financeiros em SP. Dissertação (Mestrado) Faculdade de Filosofia, Letras e Ciências Humanas, Universidade de São Paulo, 2007.
} 